JCMS

5,1

96

Received 13 October 2020

Revised 22 November 2020

1 December 2020

Accepted 1 December 2020

\section{Leverage and firm performance: new evidence on the role of economic sentiment using accounting information}

\author{
Petros Kalantonis \\ Tourism Management, School of Administrative Economics and Social Sciences, \\ University of West Attica, Athens, Greece and \\ Hellenic Open University, Patra, Greece \\ Christos Kallandranis \\ Regent's University London, London, UK, and \\ Marios Sotiropoulos \\ Tourism Management, School of Administrative Economics and Social Sciences, \\ University of West Attica, Athens, Greece
}

\begin{abstract}
Purpose - The goal of this paper is twofold. First, to examine the role of expectations in shaping agents' behaviour within an extended time frame which incorporates a prolonged harsh downturn of economic activity. Therefore, the authors allow for an indirect impact of economy-wide expectations operating via their coexistence with firms' balance sheet factors. Second, it is tested whether the behaviour of listed firms as regards to debt follows the pecking order theory.

Design/methodology/approach - The authors use the panel data methodology in the estimation of the financial structure models since unobservable heterogeneity is an important determinant towards the target leverage. A fixed effects estimation procedure, with robust intercepts allowed to vary across firms, was employed to examine the relationship between leverage and performance.

Findings - The findings offer evidence of patterns of pecking order behaviour and thus for the necessity of internal financing over external debt. The authors also extended the set of determinants by investigating the effect of macroeconomic conditions on the debt decision of firms. Contrary to the authors' expectations, shortrun beliefs of economic agents appear to play a negative role in leverage.

Originality/value - This paper contributes to the literature in a number of ways. First, following the growing literature of loan dynamics, the findings provide useful insights into corporate capital structure decisions in an economy in which businesses were almost excluded from external financing for over a decade. Second, in order to better understand corporate financing decisions, it is necessary to consider the overall economic framework in which companies and especially the listed ones operate.
\end{abstract}

Keywords Leverage, Sentiment, Size, Pecking order theory, Panel data

Paper type Research paper

\section{Introduction}

The impact of financial leverage on a firm's investment decision has been a topic of major interest amongst academics. Most of the studies, since the mid-1960s, have isolated real firm

\section{JEL Classification - C23, D82, E32, G30}

(C) Petros Kalantonis, Christos Kallandranis and Marios Sotiropoulos. Published in Journal of Capital Markets Studies. Published by Emerald Publishing Limited. This article is published under the Creative Commons Attribution (CC BY 4.0) license. Anyone may reproduce, distribute, translate and create derivative works of this article (for both commercial and non-commercial purposes), subject to full attribution to the original publication and authors. The full terms of this license may be seen at http:// creativecommons.org/licences/by/4.0/legalcode
Journal of Capital Markets Studies Vol. 5 No. 1,2021 pp. $96-107$ Emerald Publishing Limited 2514-4774

DOI 10.1108/JCMS-10-2020-0042 
decisions from financial factors. In particular, under the stringent assumptions [1] of Modigliani and Miller's (1958) irrelevance theorem, leverage is found to be irrelevant to the value of the firm. Hence, a firm's financial structure will not affect its market value in a world of perfect and complete capital markets. Subsequent studies such as that of Jensen and Meckling (1976) demonstrated the collapse of the Modigliani and Miller theorem in the presence of either asymmetric information between investors and the firm or agency costs arising from the opposite goals of managers and shareholders. In this context, Myers and Majluf (1984) with the pecking order or financial hierarchy theory of financing challenged the neutrality of financial structure vis-à-vis the value of the company. It is evident then that the capital structure literature supports that leverage and the overall value of the firm are strongly related (e.g. Myers, 1977; Fazzari et al., 1988; Whited, 1992; Aivazian et al., 2003; Umutlu 2010; Ibhagui and Olokoyo, 2019; Vo 2019).

Standard corporate finance theory investigates how financial decisions are made. In fact, the investigation of capital structure of firms and the existence of the optimum capital structure are ongoing issues in the corporate finance literature. Several theories have been developed since the seminal work of Modigliani and Miller $(1958,1963)$ and managed to deviate from the strict assumptions of perfect capital markets. In particular, two major theories emerged, namely, the trade-off theory and the pecking order theory. The former holds when firms based on tax benefits of debt construct an optimal debt ratio, while for the latter, firms prefer a sequential choice over funding sources and external funds (borrowing or issuing shares) are not sought, until own resources are exhausted.

The majority of the empirical evidence has focussed on whether leverage exerts a significant impact on the corporate performance. Previous literature shows that the effect of leverage on firms' performance is contradictory, with some research finding a negative relationship (Chen, 2004; Tian and Zeitun, 2007; Salawu, 2007) and others documenting either a favourable relationship or no significant relationship at all (e.g. Brick and Ravid, 1985; Margaritis and Psillaki, 2010; Gill et al., 2011; Azeez, 2015). In fact, Robb and Robinson (2010) advocate a positive effect of leverage on firm performance as long as the returns earned are greater than the average interest expense incurred on leverage. On the contrary, other studies (e.g. Fama and French, 1998; Negash, 2001; Phillips and Sipahioglu, 2004) reported a negative or even zero effect of leverage on company performance. However, there is a strand of the literature which attempts to measure a direct effect where essentially a given accounting variable (return on equity [ROE], return on assets [ROA], stock returns) is projected on a metric of financial structure (e.g. Dufour and Molay, 2010; Adair and Adaskou, 2015, 2018). This strand of literature has received a disproportionately low attention relative to the reverse relationship.

Despite there are quite a lot of empirical studies investigating the formation of capital structure, there are still unanswered questions (Graham et al., 2015). In particular, some determinants of debt structure have been undervalued, while too much attention has been given to firm-level characteristics. Thus, there is the possibility that other omitted variables, such as macroeconomic ones, have not received the attention they deserve. Indeed, there is a lot of research showing that during economic contractions, the access to external financing is limited (e.g. Artola and Genre, 2011) and companies' performance suffers due to a diminishing profitability. Financial decisions are not made as usual and agents change their mindset about the future prospects. Thus, in a wider context of firm characteristics, we also examine the relationship of firms' financial behaviour and that of the indirect impact of economic expectations which captures the notion of future perception of economic activity.

Indeed, Erel et al. (2012) when analysing the corporate capital structure support the necessity to incorporate factors showing that the ability of firms to access external financing depends on macroeconomic setting as well. Expectations are bound to be important in this context, given that agents' decisions of how to form the financial structure are by default 
JCMS 5,1

98

forward-looking. Hence, the macroeconomic context cannot be omitted and therefore cannot be excluded from a generalized analysis of the determinants of capital structure. Indeed, according to Greenwood and Shleifer (2014), there is evidence supporting that expectations data have a clear prognostic structure. Hence, any decision has to be made on the basis of their expectations regarding the future value of the factors that will affect the probability of successful operation, which will ultimately affect the value of the company. To capture the importance of the real economy, we look at changes in economic conditions in Greece, a traditional bank-based economy, via agents' economic sentiment. It is expected that a weaker real economy affects peoples' sentiment, which in turn is associated with lower credit demand (e.g. Lown and Morgan, 2006). In this line, the traditional "pecking order" view of corporate finance (Myers, 1984) limits or makes more costly the access to external finance, relative to internal finance.

The goal of this paper is twofold. First, to examine the role of expectations in shaping agents' behaviour within an extended time frame which incorporates a prolonged harsh downturn of economic activity. Note that sentiment indicators lead economic activity (e.g. Matsusaka and Sbordone, 1995; Bodo et al., 2000; Mourougane and Roma, 2002; Utaka, 2003, Frank and Goyal, 2009). Therefore, we allow for an indirect impact of economy-wide expectations operating via their coexistence with firms' balance sheet factors (Pindado et al., 2017).

Second, to determine the firm-specific characteristics via balance sheet items which can affect the level of leverage and overall, the financial structure of listed companies in Greece. Essentially, it is tested whether the behaviour of listed firms as regards to debt follows the pecking order theory against the trade-off theory. This paper contributes to the literature in a number of ways. First, following the growing literature of loan dynamics, the findings provide useful insights into corporate capital structure decisions in an economy in which businesses were almost excluded from external financing for over a decade. Second, in order to better understand corporate financing decisions, it is necessary to consider the overall economic framework in which companies and especially the listed ones operate. The paper is organized as follows: in the next section, we present the model and the variables considered in the analysis, in Section 3, we discuss the main results and Section 4 concludes.

\section{Literature review and background analysis}

The neoclassical theory of factor demand advocates that the firm's objective is to maximize the value of the equity owned by its shareholders so that a host of interesting corporate control issues is assumed away. In particular, the shareholders are assumed to be riskneutral; hence, any risk considering the firm's required rate of return is not taken into account. The firm issues no debt and pays no taxes so that financial policy is not considered here. Further, the firm operates in a fully competitive market and under symmetric information highlighting the existence of perfect capital markets. Much financial decision-making is based on Modigliani and Miller's theorem who verified that under perfect capital markets both capital structure and dividend policy were irrelevant to a firm's market value; hence, the firm's real decisions are unrelated to financial decisions. Hence, the cost of capital for the firm is determined by the markets, not by the financial structure of the firm. Notice that in a Modigliani-Miller environment, external financing, that is borrowing and issuing new equity shares, is a perfect substitute for internal financing, that is, cash flow and retained earnings. Along these lines, Hall and Jorgenson (1967) and Jorgenson (1963) with perfectly competitive markets distinguish between the actual capital stock and the desired or optimal capital stock, where the latter is determined by factors such as output and input prices, technology and interest rates.

However, despite the dominance of the "Irrelevance Theorem", interest in capital structure never disappeared during the period following the Modigliani-Miller (1958) study. 
Eventually, theorists came to the rescue of those who continued to believe in the importance of firm liquidity. Therefore, the separability between real and financial decisions no longer holds if the firm faces imperfect capital markets, in which internal and external financing are not perfect substitutes. Jensen and Meckling (1976) demonstrated the collapse of the Modigliani and Miller theorem in the presence of either asymmetric information between borrowers and the lenders or agency costs arising from the opposite goals of managers and shareholders. Myers (1977) shows that capital structure can influence investment decisions even without apparent market imperfection: risky debt may lead to underinvestment due to the wealth transfer from shareholders to creditors that occur upon investment. Thus, it is apparent that there are a number of factors that make firm's policy depend on its financial position.

This involved asymmetry between lenders and borrowers generate an equilibrium characterized by credit rationing (Stiglitz and Weiss, 1981). Further research showed that without fully collateralized loans, the firm's balance sheet profile is used as a signal for its creditworthiness and in addition, the perfect substitutability of external and internally generated funds breaks down (Greenwald et al., 1984; Myers and Majluf, 1984; Bernanke and Gertler, 1990; Gertler, 1992). Consequently, a cost differential, known as the external finance premium, exists between external and internal funds, with the former being more costly than the latter. This leads to the so-called financial hierarchy a "pecking order".

Pecking order theory generally explains why profitable firms have lower leverage ratios. The more profitable a firm is, the more the use of retained earnings and so the less the need to seek for external financing. This effectively means that companies facing problems in terms of profitability will turn to debt more often and will be willing to use external funds in their operation. Thus, it is evident that a negative relationship is therefore expected between profitability and debt. Mayer (1990) provides evidence for this hierarchy, showing that across industries in eight developed countries, retentions (own funds) are the leading source of finance, followed by debt (borrowing) and finally equity (issuing new shares). In this line, Vermeulen (2002) supports the hierarchy by showing that firms in Germany, France, Italy and Spain with weak balance sheets and hence, more difficult access to external financing depend more strongly on internal liquidity.

The other dominant theory of capital structure is trade-off theory. This theory which fits in the literature and assumptions initiated by Modigliani and Miller (1958) later relaxed the irrelevance theorem and included taxation (see Modigliani and Miller, 1963). Trade-off theory suggests that the optimum capital structure is set by firms in order to balance the tax advantage of debt financing, what is merely called tax shields. The most important factor affecting these tax shields is the level of firms' profitability since these firms are less likely to get bankrupt and can take advantage of debt tax shields (e.g. Fama and French, 2002). The latter leads to the conclusion that a positive relationship between profitability and debt should be expected. This is contrary to the pecking order theory.

Additionally, it is important to note that any financing transaction is taking place within a specific macroeconomic context where the company operates. Therefore, it might be useful to examine the role, if any, the macroeconomic conditions are likely to play in the debt behaviour of businesses to better understand how capital structure decisions are made. Indeed, the effect of macroeconomic factors has been highlighted in the recent literature (such as Bhamra et al., 2010; Arnold et al., 2013; Pindado et al., 2017). Hence, with respect to economic expectations, during economic expansions, peoples' sentiment becomes optimistic, stock prices go up, the balance sheets become stronger, the collateral against which the loan contracts are signed up is increased and the expected bankruptcy costs are going down. Hence, companies tend to increase their borrowing, revealing a positive interaction between leverage and economic expectations (see, for example, Kiyotaki and Moore, 1997; Levy and Hennessy, 2007; Frank and Goyal, 2009; Pindado et al., 2017). 
JCMS

5,1

100

\section{Data issues and methodology}

Our sample consists of an unbalanced panel of 154 publicly traded firms [2] of the Athens Stock Exchange Market (ASE hereafter) for the time period 2005-2018. For each year, we include the universe of firms in order to avoid introducing survivorship bias into our sample. We are bound to use the panel data methodology in the estimation of the financial structure models since unobservable heterogeneity is an important determinant towards the target leverage.

A fixed effects estimation procedure, with robust intercepts allowed to vary across firms, was employed to examine the relationship between leverage and performance. Fixed effects regression is a method for controlling for omitted variables in panel data when the omitted variables vary across entities but do not change over time. Hence, fixed effects can be used when there are two or more observations for each entity (Stock and Watson, 2020). The Hausman (1978) test indicated fixed effects as the appropriate specification. According to this approach, leverage is determined according to

$$
\left(\mathrm{LEV}_{i, t}\right)=\delta_{i}+\gamma_{1}\left(S_{i t}\right)+\gamma_{2}\left(S_{i t-1}\right)+\gamma_{3}\left(\mathrm{ROA}_{i t}\right)+\gamma_{4}\left(\mathrm{SIZE}_{i t}\right)+\gamma_{5}\left(\mathrm{ESI}_{t}\right)+\text { time dummies }+\varepsilon_{i t}
$$

where $\delta$ s and $\gamma^{\prime} s$ are unknown parameters to be estimated, $\varepsilon$ is a white noise disturbance, LEV stands for financial leverage [3], $S_{t}$ and $S_{t-1}$ are current and one year lagged annual sales over total assets capturing growth opportunities. In empirical studies, sales are frequently used instead of output as data for the former are usually more accurate (Abel and Blanchard, 1986). ROA serves as a performance indicator assessing firm's profitability, while SIZE following Rajan and Zingales (2012) is the value of firm's total assets, introduced as a key factor in firms' ability to access credit controlling for investment opportunities. We also collected seasonally adjusted monthly observations on the economic sentiment indicator (ESI) as reported by Eurostat for the period January 2005 to December 2018. Tables 1 and 2 analyse the data descriptions and summary statistics for the aforementioned variables. Hence, we circumvent the obstacle of measuring unobserved expectations by utilizing a widely accepted metric of peoples' sentiment [4]. The ESI [5] is taken from the business and consumer surveys of the Economic and Financial Affairs of the European Union (EU). The

Table 1.

Data description*

\begin{tabular}{|c|c|c|}
\hline Variable name & Symbol & Definition \\
\hline Leverage & LEV & Fraction of non-current liabilities plus loans divided by shareholder funds \\
\hline ESI & ESI & $\begin{array}{l}\text { The ESI is a composite indicator made up of the individual opinion balances of } \\
\text { five confidence indicators having different weights }\end{array}$ \\
\hline $\begin{array}{l}\text { Return on } \\
\text { assets }\end{array}$ & ROA & Fraction of net profit before tax plus interest divided by total assets \\
\hline Size & SIZE & Natural logarithm of total assets \\
\hline Sales & SALES & Annual sales over total assets \\
\hline
\end{tabular}
. 
Directorate-General for Economic and Financial Affairs conducts regularly harmonized surveys for different sectors of the economies in the EU and in the applicant countries. The data are derived from monthly surveys addressed to representatives of the industry, the services, retail trade and construction sectors, as well as to consumers. The inclusion of ESI exerts ex ante expectations since it is inherently forward-looking. An upward (downward) movement of the sentiment indicator implies that sentiment in the current period has improved (deteriorated) relative to the last period.

This measure has the following advantages: (1) it is an overall measure of sentiment embodying various aspects of the economic environment, (2) it is as close to ex ante expectations as possible since (ESI) is inherently forward-looking, (3) it is a direct measure of perceived collective level of sentiment since it is based on the answers of the business community rather than estimated, without imposing any ad hoc assumptions regarding their expectations formation mechanism, (4) it is time-varying and finally, (5) incorporates the expectations both of the supply and demand sides. Although, ESI possesses the above properties which render it an attractive measure of expectations, it also has a number of disadvantages. ESI although measured quantitatively, it clearly suffers from the lack of a direct comparison and therefore interpretation of a unit movement at different points of the scale. For instance, no straightforward comparison can be made between a unit increase, say from 91 to 92 and an increase from 92 to 93 . In other words, ESI can only be used as an indicator of the general tendency of sentiment, showing the direction rather than the magnitude.

Our priors are

(1) $\gamma_{1} \& \gamma_{2}<0$ stating that when firms are capable of generating operational income via their sales output, they tend to depend more on their own funds. The lag of sales also gives a dynamic dimension in this relationship.

(2) $\gamma_{3}<0$ as according to pecking order theory, profitable companies will give priority to internal financing unless it is exhausted.

(3) $\gamma_{4}>0$ since large firms face relatively lower risk of default and suffer less from informational asymmetries. Control for investment opportunities.

(4) $\gamma_{5}>0$ since leverage is considered as a procyclical [6] variable, firms during economic expansions tend to borrow more

\section{Discussion and results}

A fixed effects estimation procedure [7], with intercepts allowed to vary across firms, was employed to examine the relationship between investment and internal cash flows. The Hausman (1978) test indicated fixed effects as the appropriate specification. Table 3 reports the estimated results for Eqn (1).

Leverage shows a significantly positive dependence on size, which is used as a proxy for the severity of possible financial constraints. This finding was expected as information asymmetries are likely to be more severe for small firms rather for large ones (see, for example, Gertler, 1988; Hu and Schiantarelli, 1994; Gilchrist and Himmelberg, 1998; Audretsch and Elston, 2002; Gonzalez, 2012; Vithessonthi and Tongurai, 2015). Indeed, Rajan and Zingales (1995) recognize that this positive relationship is due to the fact that larger firms face lower bankruptcy costs and thus, a lower bankruptcy probability. Current sales seem to exert no significant effect, while past sales are negative and significant. This reflects that when the firm's output increases and thus, the cash inflows, the need for external financing weakens. 


\begin{tabular}{|c|c|c|}
\hline \multirow{3}{*}{$\begin{array}{l}\text { JCMS } \\
5,1\end{array}$} & \\
\hline & Variable & Eqn (1) \\
\hline & $\begin{array}{l}\text { ROA } \\
\text { SIZE } \\
\text { SALES } \\
\text { SALES }_{t-1} \\
\text { ESI }\end{array}$ & $\begin{array}{l}-6.825^{*}(4.01) \\
1.165^{* * * *}(0.29) \\
-0.020(0.16) \\
-0.286^{* * *}(0.093) \\
-0.108^{* *}(0.046)\end{array}$ \\
\hline 102 & DIAGNOSTICS & \\
\hline \multirow{2}{*}{$\begin{array}{l}\text { Table } 3 \text {. } \\
\text { Estimation results } \\
\text { (dependent variable: } \\
\text { leverage) }\end{array}$} & $\begin{array}{l}R^{2} \\
F \text {-test } \\
\text { Time dummies, } F \text {-test }\end{array}$ & $\begin{array}{l}6.13 \% \\
7.52(0.00) \\
2.12(0.018)\end{array}$ \\
\hline & \multicolumn{2}{|c|}{$\begin{array}{l}\text { Note(s): value in brackets } t \text {-stat. }(*) \text { denotes significance at the } 10 \% \text { level and }(* *) \text { denotes significance at the } \\
5 \% \text { level. The joint test of all dummies equal to } 0 \text { is rejected at the } 5 \% \text { significance level }\end{array}$} \\
\hline
\end{tabular}

Moving now to the parameters of interest, expectations, via the dynamics of ESI, appear as an important driving factor of financial structure. This is consistent with previously reported findings, where various sentiment measures contain significant forecasting power over economic decisions. Indeed, there is sound econometric evidence suggesting that confidence indicators can lead economic activity, such as gross domestic product (GDP), and also demand components such as capital if not causing them (Matsusaka and Sbordone, 1995; Bodo et al., 2000; Santero and Westerlund, 1996; Bodo et al., 2000; Lee and Shields, 2000; Lovell and Tien, 2000; Desroches and Gosselin, 2002; Mourougane and Roma, 2002; Utaka, 2003). However, and contrary to our expectations, the effect on leverage is negative, meaning that when peoples' perception is optimistic/pessimistic, the dependence on external financing is reduced/increased. Recall that ESI is a forward-looking indicator providing an overall conditional assessment of future economic conditions, which may contain a signal for future results of current decisions. Following previous literature (e.g. Kiyotaki and Moore, 1997; Levy and Hennessy, 2007; Frank and Goyal, 2009), one should expect that when the market conditions are advantageous, economic agents would possibly be more cautious in using external financing; hence, a positive relationship would emerge. Indeed, and following the financial accelerator literature, first developed by Bernanke et al. (1996), during an expansion, when monetary policy is relaxed, most of firms can finance the undertaken projects by using retained earnings while balance sheets are strong. In these periods, the demand for external finance is likely to be low.

However, one should consider a serious conditionality of the sample under scrutiny in our analysis trying to explore an alternative interpretation. Almost the $75 \%$ of the time span of our sample is linked to a period in which the Greek economy faced the most dramatic drop in its economic activity following a tight economic adjustment programme forced by the European Central Bank (ECB), International Monetary Fund (IMF) and European Commission. During this abnormal period, we have witnessed a disruption of the traditional transmission channels of monetary policy cutting off companies from external financing. In general, Greek businesses had actual no access to external financing and in particular listed companies were not even able to issue new shares as the stock market had plunged [8]. Hence, the reduced ability to access credit-drives businesses to depend solely on internal funds or even pause their operation. Indeed, during a recession, firms with weak balance sheets cannot have easy access to external finance because of the reduction in asset values and net worth, thus raising the incidence of credit rationing for all firms cancelling new investment plans. Within this unprecedented context, any effect of expectations can turn to become misleading.

Finally, our results provide evidence that the higher the profitability as depicted by the ROA, the less the firm might depend on external financing (Adair and Adaskou, 2015). 
Indeed, a significant and negative relation exists between profitability and debt structure at $10 \%$ threshold. This result confirms the existence of the pecking order theory against the trade-off theory as highly performed firms will give priority to own funds (e.g. Rajan and Zingales, 1995; Booth et al., 2001; Huang and Song, 2002; Fan et al., 2006; De Jong et al., 2008;

Chakraborty, 2010; Kayo and Kimura, 2011).

\section{Conclusions}

We empirically explored the determinants of the financial structure upon a panel of 154 Greek publicly traded companies over the 2005 to 2018 period. Essentially, we restricted the investigation to outcomes stemming from firms that are mainly the refection of the economy since as listed are mainly the most mature and large companies in the country. The setting is based on the assumption that the debt structure decisions stem from deviations from the neoclassical approach leading to capital market imperfections. Besides the a priori known balance sheet items, we examined the role of performance and the role expectations played in shaping businesses' behaviour when forming their capital structure. Essentially, we attempted to identify which of the dominant capital structure theories better explain the relationship between profitability (via ROA) and leverage and eventually the borrowing behaviour of Greek listed companies.

The findings offer evidence of patterns of pecking order behaviour and thus for the necessity of internal financing over external debt. We also extended the set of determinants by investigating the effect of macroeconomic conditions on the debt decision of firms. Contrary to our expectations, short-run beliefs of economic agents appear to play a negative role in leverage. This result is justified due to the highly extreme and abnormal conditions faced the Greek economy during the period under investigation.

The direct implication for policymakers is to be able to create the proper macroeconomic conditions that facilitate the access of companies to debt financing alleviating possible informational asymmetries such as adverse selection and moral hazard. Although expectations follow up from economic conditions, policymakers have the power to create the necessary institutional framework. Indeed, as Pindando et al. (2017) highlight, the promotion of the information flow between parties in the lending process will act beneficially, especially during economic contractions as in the case of Greece. In this line, Freel et al. (2012) support that in countries which have achieved to reduce information asymmetries, firms have easier access to credit.

\section{Notes}

1. The irrelevance of capital structure was founded upon a number of restrictive assumptions ignoring transaction costs, taxes or inflation, the equality of borrowing and lending rates and independence of financing and investment decisions.

2. Banks, leasing, holding and insurance companies were excluded from the sample. 43 out of 154 stocks were at least once year under suspension throughout the period under investigation.

3. We make use of a non-current debt measure as dependent variable because of our focus on how the effect of macroeconomic factors affects firm's capital structure (Korajczyk and Levy, 2003).

4. For a good review, see Kallandranis Christos PhD Thesis 2007: "Topics on the Dynamics of Capital and Labour Demand: An Empirical Analysis".

5. The ESI is a composite indicator made up of the individual opinion balances of five confidence indicators having different weights (industrial confidence indicator: $40 \%$, services confidence indicator: $30 \%$, consumer confidence indicator: $20 \%$, retail trade indicator: $5 \%$ and construction confidence indicator: $5 \%$ ). Each indicator is calculated as the simple arithmetic average of the (seasonally adjusted) balances of answers to specific questions. 
JCMS 5,1

\section{4}

6. Since collateral values are likely to be procyclical and firms borrow against collateral, leverage should be procyclical as well (Pindando et al., 2017).

7. For space considerations, estimation results obtained using the random effects estimator are not reported here, even though the results do not change dramatically. The results are available upon request.

8. Note that from 2009 to 2018, the sentiment indicator in Greece was plunged staying almost consistently below the 100-unit threshold, and during this time, there was a deleveraging process by firms in order to secure their place amidst the economic turmoil.

\section{References}

Abel, A. and Blanchard, O. (1986), "The present value of profits and cyclical movements in investment", Econometrica, Vol. 54 No. 2, pp. 249-273.

Adair, P. and Adaskou, M. (2015), "Trade-off theory vs. pecking order theory and the determinants of corporate leverage: evidence from a panel data analysis upon French SMEs (2002-2010)", Cogent Economics and Finance, Vol. 3 No. 1, pp. 1-9.

Adair, P. and Adaskou, M. (2018), "The capital structure of mature French SMEs and impact of the great recession: a dynamic panel data analysis (2002-2010)", Economics, Management and Sustainability, Vol. 3 No. 2, pp. 60-75, doi: 10.14254/jems.2018.3-2.5.

Aivazian, V., Ge, Y. and Qiu, J. (2003), "The impact of leverage on firm investment: Canadian evidence", Journal of Corporate Finance, Vol. 11 Nos 1-2, pp. 277-291.

Arnold, M., Wagner, A.F. and Westermann, R. (2013), "Growth options, macroeconomic conditions, and the cross section of credit risk", Journal of Financial Economics, Vol. 107 No. 2, pp. 350-385.

Artola, C. and Genre, V. (2011), "Euro area SMEs under financial constraints: belief or reality?", CESifo Working Paper Series, No. 3650.

Audretsch, D. and Elston, J. (2002), "Does firm size matter?: evidence on the impact of liquidity constraints on firm investment”, International Journal of Industrial Organization, Vol. 20, pp. 1-16.

Azeez, A. (2015), “Corporate governance and firm performance: evidence from Sri Lanka”, Journal of Finance and Bank Management, Vol. 3 No. 1, pp. 180-189.

Bernanke, B. and Gertler, M. (1990), "Financial fragility and economic performance”, Quarterly Journal of Economics, Vol. 105, pp. 97-114.

Bernanke, B., Gertler, M. and Gilchrist, S. (1996), "The financial accelerator and the flight to quality", Review of Economics and Statistics, Vol. 78 No. 1, pp. 1-15.

Bhamra, H.S., Kuehn, L. and Strebulaev, I.A. (2010), "The aggregate dynamics of capital structure and macroeconomic risk", Review of Financial Studies, Vol. 23 No. 12, pp. 4187-4241.

Bodo, G.R., Gonelli, R. and Parigi, G. (2000), "Forecasting industrial production in the euro area economy", Empirical Economics, Vol. 25, pp. 541-561.

Booth, L., Aivazian, V., Demirguc-Kunt, A. and Maksimovic, V. (2001), "Capital structures in developing countries", The Journal of Finance, Vol. 56, pp. 87-130.

Brick, I.E. and Ravid, S.A. (1985), "On the relevance of debt maturity structure", The Journal of Finance, Vol. 40, pp. 1423-1437.

Chakraborty, I. (2010), "Capital structure in an emerging stock market: the case of India", Research in International Business and Finance, Vol. 24, pp. 295-314.

Chen, Y. and Wang, S. (2004), "The empirical evidence of the leverage effect on volatility in international bulk shipping market”, Maritime Policy and Management, Vol. 31 No. 2, pp. 109-124.

De Jong, A., Kabir, R. and Nguyen, T.T. (2008), "Capital structure around the world: the roles of firmand country-specific determinants", Journal of Banking and Finance, Vol. 32 No. 9, pp. 1954-1969. 
Desroches, B. and Gosselin, A. (2002), "The usefulness of consumer confidence indexes in the United States", Bank of Canada, Working Paper, No. 2002-22.

Dufour, D. and Molay, E. (2010), "La structure financière des PME françaises : une analyse sectorielle sur données de panel' [The financial structure of French SMEs: a sector analysis on panel data]", Paper presented at the 31st Conference of the Francophone Accounting Association: Crises et nouvelles problématiques de la Valeur, Nice: France, pp. 1-18.

Erel, I., Julio, B., Kim, W. and Weisbach, M.S. (2012), "Macroeconomic conditions and capital raising", Review of Financial Studies, Vol. 25 No. 2, pp. 341-376.

Fama, E.F. and French, K.R. (1998), "Value versus growth: the international evidence", Journal of Finance, pp. 1975-1998.

Fama, E.F. and French, K.R. (2002), "Testing trade-off and pecking order predictions about dividends and debt", Review of Financial Studies, Vol. 15, pp. 1-33.

Fan, J., Titman, S. and Twite, G. (2006). "An international comparison of capital structure and debt maturity choices", AFA 2005 Philadelphia Meetings.

Fazzari, S., Hubbard, R. and Petersen, B. (1988), "Financing constraints and corporate investment", Brookings Papers on Economic Activity, Vol. 19, pp. 141-195.

Frank, M.Z. and Goyal, V.K. (2009), "Capital structure decisions: which factors are reliably important?", Financial Management, Vol. 38 No. 1, pp. 1-37.

Freel, M., Carter, S.T. and Mason, C. (2012), "The latent demand for bank debt: characterizing discouraged borrowers", Small Business Economics, Vol. 38, pp. 399-418.

Gertler, M. (1988), "Financial structure and aggregate economic activity: an overview", Journal of Money, Credit, and Banking, Vol. 20 part 2, pp. 559-596.

Gertler, M. (1992), "Financial capacity and output fluctuations in an economy with multiperiod financial relationships", Review of Economic Studies, Vol. 59, pp. 455-472.

Gilchrist, S. and Himmelberg, C. (1998), "Investment fundamentals, and finance", NBER Working Paper Series, No. 6652.

Gill, A. and Mathur, N. (2011), "Factors that influence financial leverage of Canadian firms", Journal of Applied Finance and Banking, Vol. 1, pp. 1-2.

González, V.M. (2012), "Leverage and corporate performance: international evidence”, International Review of Economics \& Finance, Vol. 25, pp. 169-184.

Graham, J.R., Leary, M.T. and Roberts, M.R. (2015), "A century of capital structure: the leveraging of corporate America”, Journal of Financial Economics, Vol. 118 No. 3, pp. 658-683.

Greenwald, B., Stiglitz, J. and Weiss, A. (1984), "Information imperfections and macroeconomic fluctuations", American Economic Review, Vol. 74, pp. 194-199.

Greenwood, R. and Andrei, S. (2014), "Expectations of returns and expected returns", Review of Financial Studies, Vol. 27 No. 3, pp. 714-746.

Hall, R. and Jorgenson, D. (1967), "Tax policy and investment behavior", American Economic Review, Vol. 57, pp. 391-414.

Hausman, J.A. (1978), "Specification tests in econometrics”, Econometrica, Vol. 46, pp. 1251-1271.

$\mathrm{Hu}, \mathrm{X}$. and Schiantarelli, F. (1994), "Investment and financing constraints: a switching regression approach using US firm panel data", Review of Economics and Statistics, Vol. 80, pp. 466-479.

Huang, S.G. and Song, F.M. (2002), "The determinants of capital structure: evidence from China, Hong Kong institute of economics and business strategy", Working Paper, No. 1042.

Ibhagui, W.O. and Olokoyo, F.O. (2019), "Leverage and firm performance: new evidence on the role of firm size", The North American Journal of Economics and Finance, Vol. 45 No. 2018, pp. $57-82$.

Jensen, M. and Meckling, W. (1976), "Theory of the firm: managerial behaviour, agency costs and capital structure", Journal of Financial Economics, Vol. 3, pp. 305-360.

Leverage and firm performance

\section{(1)}


JCMS

5,1

106

Jorgenson, D. (1963), "Capital theory and investment behavior", American Economic Review, Vol. 57, pp. 247-259.

Kallandranis, C. (2007), Topics on the Dynamics of Capital and Labour Demand: an Empirical Analysis, $\mathrm{PhD}$ Thesis, University of Patras.

Kayo, K.E. and Kimura, H. (2011), "Hierarchical determinants of capital structure”, Journal of Banking and Finance, Vol. 35 No. 2, pp. 358-371.

Kiyotaki, N. and Moore, G. (1997), “Credit cycles”, Journal of Political Economy, Vol. 105, pp. 211-248.

Korajczyk, R.A. and Levy, A. (2003), "Capital structure choice: macroeconomic conditions and financial constraints", Journal of Financial Economics, Vol. 68 No. 1, pp. 75-109.

Lee, K. and Shields, K. (2000), "Expectations formation and business cycle fluctuations: an empirical analysis of actual and expected output in UK manufacturing, 1975-1996", Oxford Bulletin of Economics and Statistics, Vol. 62 No. 4, pp. 463-490.

Levy, A. and Hennessy, C. (2007), "Why does capital structure choice vary with macroeconomic conditions?”, Journal of Monetary Economics, Vol. 54 No. 6, pp. 1545-1564.

Lovell, C. and Tien, P. (2000), "Economic discomfort and consumer sentiment", Eastern Economic Journal, Vol. 26 No. 1, pp. 1-7.

Lown, C. and Morgan, D.P. (2006), "The credit cycle and the business cycle: new findings using the loan officer opinion survey", Journal of Money, Credit, and Banking, Vol. 38 No. 6, pp. 1575-1597.

Margaritis, D. and Psillaki, M. (2010), "Capital structure, equity ownership and firm performance", Journal of Banking and Finance, Vol. 34 No. 3,2010, pp. 621-632.

Matsusaka, J. and Sbordone, A. (1995), "Consumer confidence and economic fluctuations", Economic Inquiry, Vol. 33 No. 2, pp. 296-318.

Mayer, C. (1990), "Financial systems, corporate finance, and economic development", in Hubbard, R. (Ed.), Asymmetric Information, Corporate Finance and Investment, University of Chicago Press, Chicago, IL.

Modigliani, F. and Miller, H. (1958), "The cost of capital, corporation finance, and the theory of investment”, American Economic Review, Vol. 48, pp. 261-297.

Modigliani, F. and Miller, M.H. (1963), "Corporate income taxes and the cost of capital: a correction”, American Economic Review, Vol. 53, pp. 433-443.

Mourougane, A. and Roma, M. (2002), "Can confidence indicators be useful to predict short term real GDP growth?”, European Central Bank, Working Paper, No. 133.

Myers, S. (1977), "Determinants of corporate borrowing”, Journal of Financial Economics, Vol. 5, pp. 147-175.

Myers, S. (1984), “The capital structure puzzle”, Journal of Finance, Vol. 39, pp. 575-592.

Myers, S.C. and Majluf, N.S. (1984), "Corporate financing and investment decisions when firms have information that investors do not have", Journal of Financial Economics, Vol. 13, pp. 187-221.

Negash, M. (2001), "Debt, tax shield and bankruptcy costs: some evidence from JSE", Investment Analysts Journal, Vol. 30, pp. 33-44.

Phillips, P. and Sipahioglu, M. (2004), "Performance implications of capital structure: evidence from quoted UK organisations with hotel interests", Service Industries Journal - SERV IND J., Vol. 24, pp. 31-51.

Pindado, J., Requejo, I. and Rivera, J.C. (2017), "Economic forecast and corporate leverage choices: the role of the institutional environment", International Review of Economics and Finance, Vol. 51, pp. 121-144.

Rajan, R.G. and Zingales, L. (1995), "What do we know about capital structure? Some evidence from international data", The Journal of Finance, Vol. 50, pp. 1421-1460. 
Rajan, R.G. and Zingales, L. (2012), "What do we know about capital structure? Some evidence from international data", The Journal of Finance, Vol. 50, pp. 1421-1460.

Robb, A. and Robinson, D. (2010), "The capital structure decisions of new firms", National Bureau of Economic Research, NBER Working Papers, 27.

Salawu, R. (2007), "An empirical analysis of the capital structure of selected quoted companies in Nigeria”, The International Journal of Applied Economics and Finance, Vol. 1 No. 1, pp. 16-28.

Santero, T. and Westerlund, N. (1996), "Confidence indicators and their relationship to changes in economic activity", OECD, Economic Department, Working Papers, No. 170.

Leverage and firm performance

Stiglitz, J. and Weiss, A. (1981), "Credit rationing in markets with imperfect information", American Economic Review, Vol. 71, pp. 393-410.

Stock, H.J. and Watson, W.M. (2020), Introduction to Econometrics, 4th ed., Pearson, London.

Tian, G.G. and Zeitun, R. (2007), "Capital structure and corporate performance: evidence from Jordan”, Australian Accounting Bussiness and Finance Journal, Vol. 1 No. 4, pp. 40-61.

Umutlu, M. (2010), "Firm leverage and investment decisions in an emerging market", Quality and Quantity, Vol. 44, pp. 1005-1013.

Utaka, A. (2003), "Confidence and the real economy-the Japanese case", Applied Economics, Vol. 35, pp. 337-342.

Vermeulen, P. (2002), "Business fixed investment: evidence of a financial accelerator in europe", Oxford Bulletin of Economics and Statistics, Vol. 64 No. 3, pp. 213-231.

Vithessonthi, C. and Tongurai, J. (2015), "The effect of leverage on performance: domestically-oriented versus internationally-oriented firms", Research in International Business and Finance, Vol. 34 No. 2015, pp. 265-280.

Vo, X.V. (2019), "Leverage and corporate investment - evidence from Vietnam”, Finance Research Letters, Vol. 28, pp. 1-5.

Whited, T. (1992), "Debt, liquidity constraints, and corporate investment: evidence from panel data", Journal of Finance, Vol. 47, pp. 1425-1460.

\section{Further reading}

Brounen, D., de Jong, A. and Koedijk, K. (2006), "Capital structure policies in Europe: survey evidence", Journal of Banking \& Finance, Vol. 30 No. 5, pp. 1409-1442.

Julio Pindado, J., Requejo, I. and Rivera, J.C. (2017), "Economic forecast and corporate leverage choices: the role of the institutional environment", International Review of Economics and Finance, Vol. 51, pp. 121-144.

Mayers, S. and Majluf, N. (1984), "Corporate financing and investment decisions when firms have information that investors do not have", Journal of Financial Economics, Vol. 13, pp. 187-221.

Ziane, Y. (2004), Structure Financière, Relations Bancaires De Long Terme Et Financement Interentreprises Des Pme Françaises [Financial Structure, Long-Term Banking Relationships and the Intercompany Financing of French SMEs], Unpublished $\mathrm{PhD}$ thesis, Universite Paris, Nanterre, Vol. 10.

\section{Corresponding author}

Christos Kallandranis can be contacted at: kallandrac@regents.ac.uk

For instructions on how to order reprints of this article, please visit our website:

www.emeraldgrouppublishing.com/licensing/reprints.htm

Or contact us for further details: permissions@emeraldinsight.com 